\title{
ROLE OF VITAMINS IN AMELIORATING THE BIOLOGICAL WASTEWATER TREATMENT BY ALGAE
}

\author{
Nadia H. Noaman, Abdel Fattah M. Kahleafa, Mona I. Abdel Nabi \\ Botany department, Faculty of Science, Alexandria University, \\ Alexandria, Egypt.
}

\begin{abstract}
This study evaluated the effect of different concentrations of vitamins, $\mathrm{B}_{12}$ and $\mathrm{C}$ in the process of wastewater treatment by the blue - green algae Synechocystis aquatilis and Chroococcus schizodermaticus. C. schizodermaticus was more efficient than S. aquatilis in removing phosphorus by using both vitamins at all concentrations, while maximum nitrate removal was attained after 20 days using vitamin $\mathrm{C}$ at concentration 25 $\mathrm{mg} / \mathrm{l}$ in case of C. schizodermaticus reactor. Vitamin $\mathrm{B}_{12}$ caused the accumulation of nitrate in both algal reactors after 6 days at concentration $50 \mathrm{mg} / \mathrm{l}$, while that accumulation began after 8 days with the use of concentration $75 \mathrm{mg} / \mathrm{l}$. Concentration $25 \mathrm{mg} / \mathrm{l}$ of vitamin $\mathrm{B}_{12}$ caused accumulation after 6 days in C. schizodermaticus reactor and after 12 days at $S$. aquatilis reactor. Ammonia was completely disappeared from wastewater treated by C. schizodermaticus using vitamin $\mathrm{B}_{12}$ (concentration $75 \mathrm{mg} / \mathrm{l}$ ) and vitamin $\mathrm{C}$ at its three concentrations in C. schizodermaticus reactors and only at concentration $25 \mathrm{mg} / \mathrm{l}$ in case of $S$. aquatilis reactor.
\end{abstract}

Key words: Wastewater treatment, vitamins, Synechocystis aquatilis, Chroococcus schizodermaticus.

\section{Introduction}

Microalgae have a vast industrial and economic potential as valuable sources for pharmaceuticals, health food, carotenoids, dyes, fine chemicals, biofuels and other applications (Faulkner 1986). The history of the commercial use of algal cultures spans about 50 years resulting in various applications as valuable sources for pharmaceuticals, health foods, carotenoids, dyes, fine chemicals and biofuels (Radmer 1996, and Borowitzka, 1999). Furthermore, they may serve as a solution to emerging environmental problems such as greenhouse effect and waste treatments (Nagase et al., 1998 and Hirata 1996) because they can fix carbon dioxide by photosynthesis and remove excess nutrients efficiently at a minimal cost (Murakami and Lkenouchi 1997, Akimoto et al., 1998 and Hirano et al., 1997).

Many wastewaters are lacking in the nutrients required for microbial growth. A number of nutrients are essential for metabolic activity. A wide range of micronutrients including vitamins are required by activated sludge (Lind et al., 1994, Lemmer et al., 1998). Sufficient micro-nutrition is needed to support all the genera required for activated sludge to treat wastewater. 
Many factors affect the process of wastewater treatment like organic nitrogen sources (Lau et al., 1994), micro-nutrients (Burgess et al., 1999), light (Lee \& Lee 2001), vitamins (He and Hader, 2002) and aeration (Lee \& Lee 2002).

Vitamin supplementation is advertised in wastewater treatment to compensate for a deficiency of growth factors and thereby increase sludge activity and purification efficiency. Addittion of vitamins of the B- complex was tested with activated sludge by Lemmer et al. (1998). This work was performed to throw light on the role of vitamin $B_{12}$ and vitamin $C$ on the process of wastewater treatment by two cyanobacterial species.

\section{Material and Methods}

Cyanobacterial growth and culture conditions

Two cyanobacterial taxa were used in this study, Synechocystis aquatilis Sauvageau and Chroococcus schizodermaticus Nageli. They were obtained from Trepon Culture Collection at Czech Republic. Both algae were inoculated in 500 ml culture flasks in BGII medium (Vonshak, 1986). The cultures were incubated at $35^{\circ} \mathrm{C}$ and continuous light intensity of 3000 Lux.

\section{Wastewater treatment}

Primary treatment carried out through the preliminary sieving step at station to get-rid of the large suspended solids. Wastewater sample was supplied from Wastewater Treatment Station at Abees district, Alexandria City, Egypt.

\section{Sampling and analyses}

Water samples were analyzed for $\mathrm{NH}_{4}^{+} \mathrm{N}$ and $\mathrm{NO}_{3}^{-} \mathrm{N}$ following the methods described by Markus et al. (1982), while $\mathrm{PO}^{3-}{ }_{4}-\mathrm{P}$ was analysed according to the method of APHA (1985). The recorded results represent the mean values of three replicates of determinations.

\section{Statistical analysis:}

Data obtained in the present investigation were statistically analyzed using the Least Significant Difference test (LSD) at 1\% and 5\% levels of probability (Snedecor and Cochran, 1967).

\section{Results}

Table 1 shows the effect of different concentrations of vitamin $B_{12}$ on the process of removing ammonium-nitrogen from wastewater. It is clear that concentration $75 \mathrm{mg} / \mathrm{l}$ gave the maximum ammonium-nitrogen removal (100\%) by Chroococcus schizodermaticus after only 18 days. Synechocystis aquatilis caused 97.75\% ammonium-nitrogen removing after 20 days.

Statistically, no significant difference between the two algal reactors in ammonium-nitrogen removal by the three concentrations of vitamin $\mathrm{B}_{12}$, while high significant difference between each of the algal reactor and the control reactor in case of concentrations 50 and $75 \mathrm{mg} / \mathrm{l}$. Concentration $25 \mathrm{mg} / \mathrm{l}$ gave significant difference between $C$. schizodermaticus and the control reactor and unsignificant difference between $S$. aquatilis and the control reactor. 
The data in table 2 shows that nitrate-nitrogen concentration increased by addition of vitamin $B_{12}$ at the three used concentrations and concentration $25 \mathrm{mg} / \mathrm{l}$ caused the highest increasing of nitrate concentration in S. aquatilis reactor, while concentration $75 \mathrm{mg} / \mathrm{l}$ caused the highest nitrate concentration in $C$. schizodermaticus reactor after 20 days.

No significant difference in nitrate-nitrogen removal between the two algal reactors by using the three concentrations of vitamin $B_{12}$, while significant difference appeared only between $C$. schizodermaticus and the control reactor in case of using concentration $25 \mathrm{mg} / \mathrm{l}$ (L.S.D. at $1 \%$ and $5 \%$ levels were 50.7 and 37.2, respectively,). High significant difference was also present between the control and each of the algal reactors in case of concentration 50 and $75 \mathrm{mg} / \mathrm{l}$ of vitamin $\mathrm{B}_{12}$.

Results in table 3 show the high efficiency of both algae in removing phosphorus by addition of vitamin $B_{12}$. Concentration $25 \mathrm{mg} / \mathrm{l}$ caused maximum removing of phosphorus $(99.13 \%)$ by $C$. schizodermaticus, while concentration $75 \mathrm{mg} / \mathrm{l}$ caused maximum phosphorus removing (97.63\%) by C. schizodermaticus after 20 days.

In the three concentrations of vitamin $\mathrm{B}_{12}$, the difference in phosphorus removal between the three reactors is not significant (L.S.D. was 3.2 and 2.4 at $1 \%$ and at $5 \%$ levels respectively, by using concentration $25 \mathrm{mg} / \mathrm{l}$. Concentration $50 \mathrm{mg} / \mathrm{l}$ showed L.S.D. 2.9 and 2.2 at $1 \%$ and $5 \%$ levels, respectively, while concentration $75 \mathrm{mg} / \mathrm{l}$ showed L.S.D. 3.1 and 2.3 at 1 and $5 \%$ levels, respectively.

Data in table 4 show the effect of different concentrations of vitamin $C$ on the ammonium-nitrogen removal from wastewater. Concentration $25 \mathrm{mg} / \mathrm{l}$ of vitamin $\mathrm{C}$ caused the highest removal of ammonium- nitrogen in both algal reactors $(100 \%)$ after 12 days in case of C. schizodermaticus reactor and after 16 days in case of $S$. aquatilis reactor, while concentration $50 \%$ caused that highest percentage of removing only in case of $C$. schizodermaticus reactor after 16 days. $100 \%$ ammonium- nitrogen removal appeared at $C$. schizodermaticus reactor after 18 days by using $75 \mathrm{mg} / \mathrm{l}$ of vitamin C. Concentration $25 \mathrm{mg} / \mathrm{l}$ of vitamin $\mathrm{C}$ is considered the best one for the complete removing of ammonium- nitrogen by $C$. schizodermaticus after 12 day, while concentration 50 and $75 \mathrm{mg} / \mathrm{l}$ of vitamin $\mathrm{B}_{12}$ are the best for ammonium- nitrogen removal by $S$. aquatilis and caused a removal percentage of $97.75 \%$ after 20 days.

No significant difference between the three reactors in ammoniumnitrogen removing in the three used concentration of vitamin $\mathrm{C}$. By using the concentration $25 \mathrm{mg} / \mathrm{l}$ of vitamin C, L.S.D. at $1 \%$ and $5 \%$ levels were 7.3 and 5.4, respectively. At concentration $50 \mathrm{mg} / \mathrm{l}$, L.S.D. at $1 \%$ level was 6.5 and at $5 \%$ levels was 4.8 while at concentration $75 \mathrm{mg} / \mathrm{l}$, L.S.D. at $1 \%$ level was 6.8 and at $5 \%$ level was 5.0. 

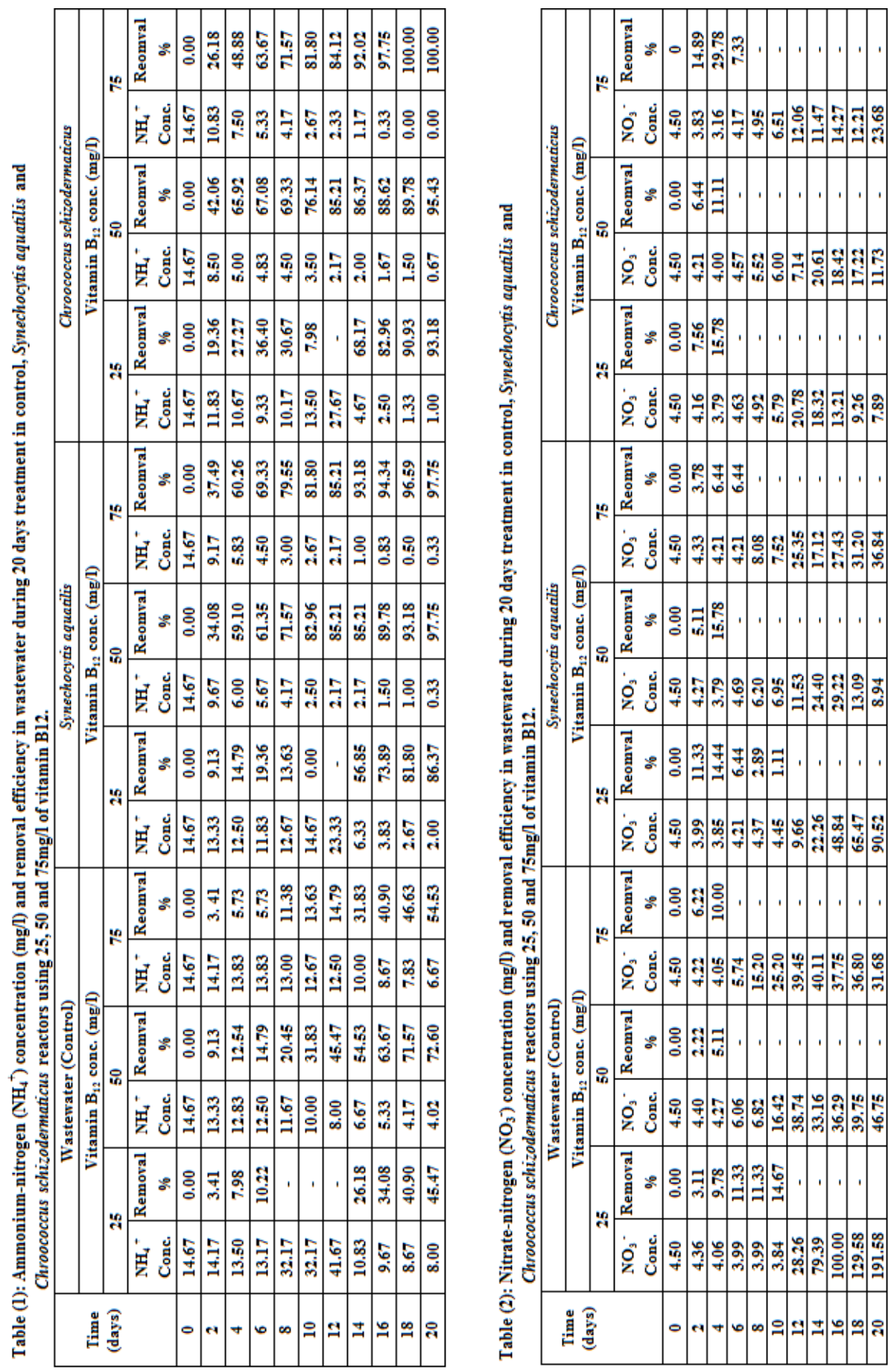

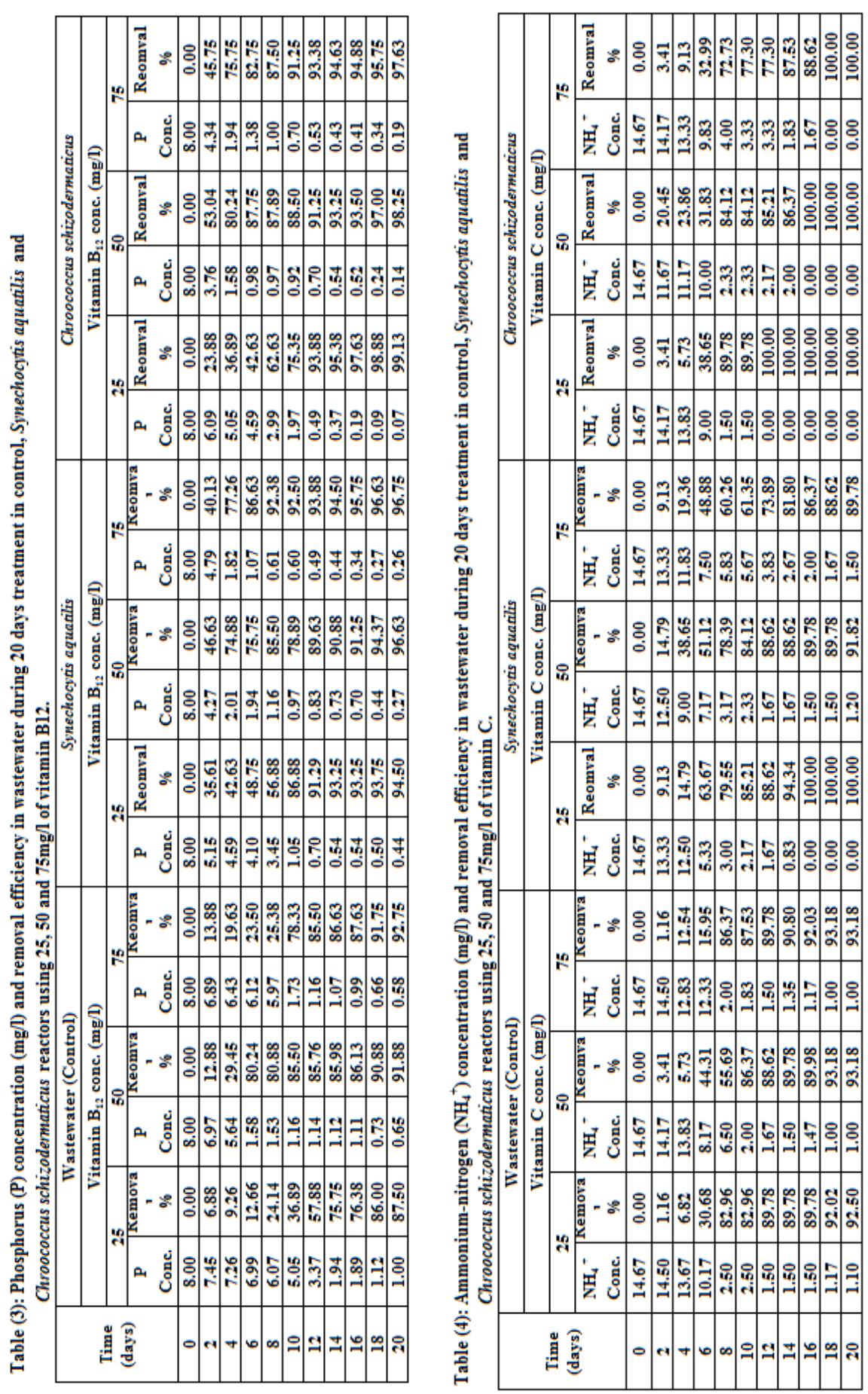
Table 5 shows that vitamin $\mathrm{C}$ at its three concentrations caused no removing of nitrate- nitrogen from wastewater in both algal reactors and nitrate concentration increased.

The difference between the two algal reactors in nitrate-nitrogen removal is not significant by using the concentration 50 and $75 \mathrm{mg} / \mathrm{l}$ of vitamin $\mathrm{C}$ but was significant at concentration $25 \mathrm{mg} / \mathrm{l}$. The reactors of $C$. schizodermaticus showed high significant difference with the control reactor at the three concentrations, while $S$. aquatilis reactor showed not significant difference compared to the reactor by using the concentrations 25 and $50 \mathrm{mg} / \mathrm{l}$ and showed high significant difference with control at concentration $75 \mathrm{mg} / \mathrm{l}$.

Table 6 proves that concentration $25 \mathrm{mg} / \mathrm{l}$ of vitamin $\mathrm{C}$ was the most suitable concentration for removing phosphorus by $C$. schizodermaticus, while concentration $75 \mathrm{mg} / \mathrm{l}$ caused maximum removal of phosphorus by $S$. aquatilis after 20 days. It must be mentioned that vitamin $B_{12}$ is more effective for the process of removing phosphorus by both algae than vitamin $\mathrm{C}$, while vitamin $\mathrm{C}$ concentration $25 \mathrm{mg} / \mathrm{l}$ caused the highest ammonium removal by both algae after 12 days in case of C.schizodermaticus and after 16 days in case of $S$. aquatilis.

High significant difference appeared between each of the algal reactor and the control but no significant difference between the two algal reactors in phosphorus removal by addition of the three concentrations of vitamin $\mathrm{C}$. At concentration $25 \mathrm{mg} / \mathrm{l}$ of vitamin C, L.S.D. at $1 \%$ and $5 \%$ levels were 2.5 and 1.8 , respectively, while they were 2.3 and 1.7 respectively, at concentration $50 \mathrm{mg} / \mathrm{l}$. Concentration $75 \mathrm{mg} / \mathrm{l}$ of vitamin C, L.S.D. at $1 \%$ level was 1.8 and at $5 \%$ level was 2.4 .

\section{Discussion}

Concerning the fate of vitamins inside the cells of both algae, vitamin $B_{12}$ was proved to be converted to coenzymes form of $\mathrm{B}_{12}$ in Chlamydowonas reinhardtii (Watanabe et al., 1991) and Pleurochrysis carterae (Miyamoto et al., 2002).

The increase of activity of both algae in uptaking ammonium nitrogen and phosphorus may return to the increase in the growth of both algae. Addition of vitamins to the algal cultures was proved to increase growth significantly (Zhang et al., 1997).

Optical density of the alga Chattonella antique showed a significant increase by addition of vitamin $B_{2}$ to the cultured medium. The increase seemed to be due to an accumulation of reduced ferrodoxin caused by the inhibition of ferrodoxin NADP reductase by the vitamin (Furuki and Tachibana, 1986). Ascorbic acid was found by El-Naggar and El- Sheekh (1998) to accelerate the growth and chlorophyll content of Chlorella vulgaris and the enhancement is a dose dependent. 
Role of Vitamins in Ameliorating the Biological Wastewater Treatment by Algae
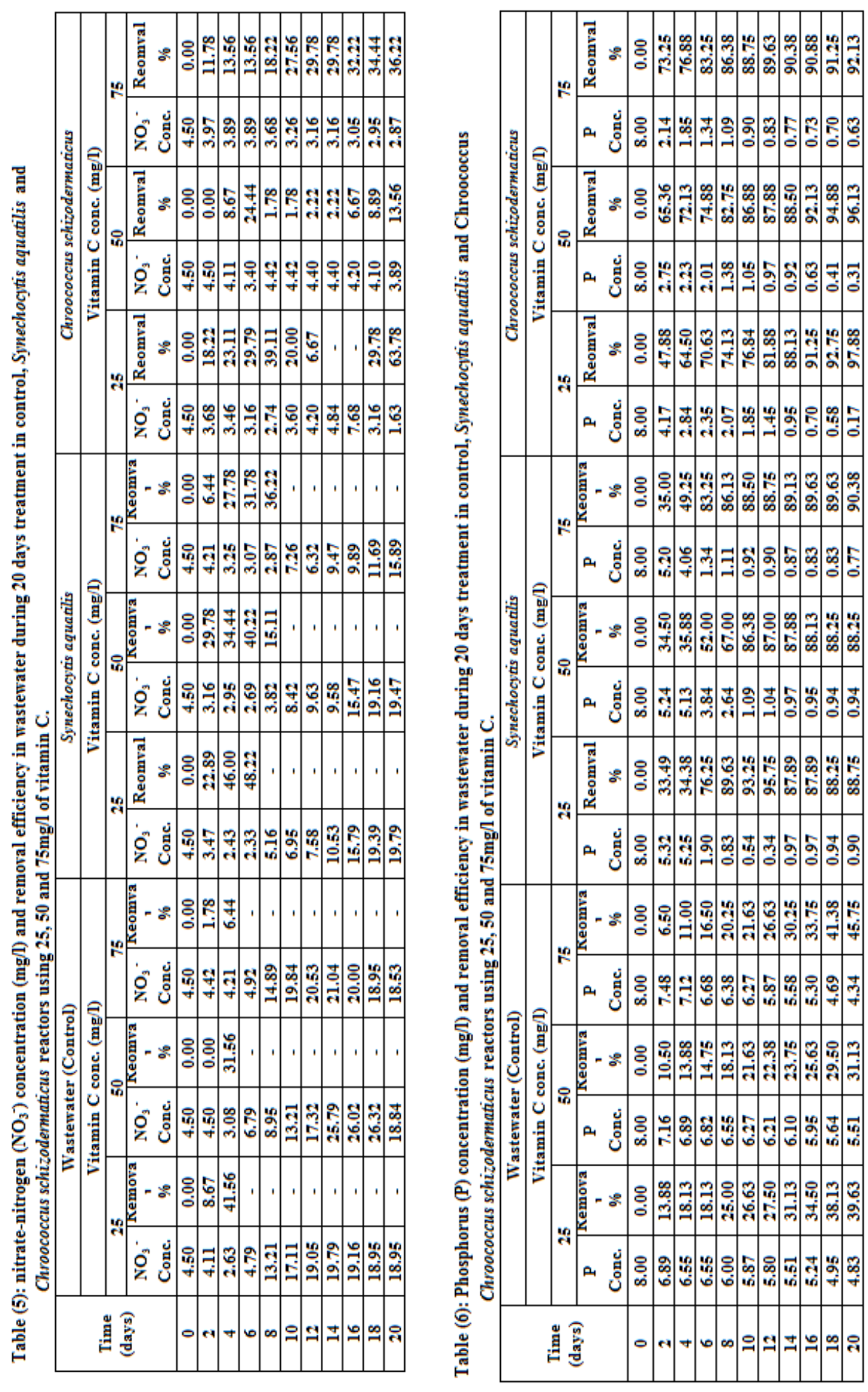
Increasing the organic carbon (like vitamins) content in the culture accelerates the growth and metabolic processes of phytoplankton by reducing the cellular uptake of heavy metals (Sudhakar et al., 1991).

The high activity for nutrients removal by both algae may return to reverse the harmful effect of wastewater. Gowrinathan and Rao (1992) attributed the reversal of heavy metal toxicity by ascorbic acid in diatoms to two possible mechanisms 1-ascorbic acid may act as a reducing agent, protecting the oxidation of the SH group by photosystem 11 or 2 - ascorbic acid may bind metals thereby affecting their movement across biological membranes. Rai and Raizada (1988) proved that Nostoc muscorum could be protected from heavy metal toxicity by supplementing ascorbic acid. They postulated that ascorbic acid can protect against metal toxicity possibly by providing a reducing power which protects the enzymes from undergoing oxidation.

The presence of vitamin $\mathrm{C}$ was found to protect the algae from chlorophyll bleaching and damage of photosynthetic apparatus (He \& Hader, 2002). Ascorbic acid can reverse mercury, chromium and lead toxicities in algal cells (Gowrinathan \& Rao, 1992 and El-Naggar \& El-Sheekh, 1998).

The high removal percentage in presence of vitamin $C$ could be attributed to the action of vitamin $\mathrm{C}$ as antioxidant in plants and its pivotal role in the destruction of reactive oxygen species (Foyer \& Ferrario, 1994, Padh, 1990, Liebler et al., 1986 and He \& Hader 2002).

Vitamins were proved by Burgess et al. (1999) to activate the process of wastewater treatment.

Nitrate was successfully reduced by Chlorella kessleri to below $2 \mathrm{mg}$ from the initial nitrate concentration of $140 \mathrm{mg}$ in 10 days (Lee \& Lee, 2002). This disagreed with our results which showed that nitrate accumulated in the reactors.

Presence of large amounts of ammonium produced protons, reducing the $\mathrm{pH}$. The low $\mathrm{pH}$ condition must have had a harmful effect on algal growth and thus nitrogen consumption (Lee \& Lee, 2002). Syrett (1981) found that in presence of active nitrate reductase and $\mathrm{NO}_{3}^{-}$uptake system, the addition of $\mathrm{NH}_{4}{ }^{+}$could lead to a rapid cessation of $\mathrm{NO}_{3}^{-}$utilization. Vymazal (1995) pointed out that active nitrate reductase is not formed in the presence of $\mathrm{NH}_{4}^{+}$nor in the $\mathrm{NO}_{3}{ }^{-}$uptake system.

The above mentioned facts could explain why in the $S$. aquatilis and $C$. schizodermaticus reactors, nitrate persisted and even accumulated in wastewater.

Ammonia oxidizing bacteria (AOB) cause the nitrification process which may be the cause of increase of nitrate concentration. AOB were found within and between different reactors of treating wastewater. They were most closely related to Nitrosococcus mobilis and Nitrosomonas halophila (Rowan et al., 2003). 


\section{References}

Akimoto, M.; Shirai, A.; Ohtaguchi, K. and Koide, K. (1998). Carbon dioxide fixation and polyunsaturated fatty acid production by the red alga Porphyridium cruentum. Appl. Biochem. Biotechnol., 73: 269.

APHA, AWWA and WPCF (1985). Standard methods for the examination of water and wastewater. $16^{\text {th }}$ edition.

Borowitzka, M. A. (1999). Commercial production of microalgae. Ponds, tanks, tubes and fermenters. J. Biotechnol., 70: 313.

Burgess, J. E.; Quarmby, J. and Stephenson, T. (1999). Micronutrient supplements for optimization of the treatment of industrial wastewater using activated sludge. Water Res., 33 (18): 3707.

Craggs, R. J.; McAuley, P. J. and Smith, V. J. (1997). Wastewater nutrient removal by marine microalgae grown on a corrugated raceway. Water Res., 31: 1701 .

El-Naggar, A. H. and El-Sheekh, M. M. (1998). Abolishing cadmium toxicity in Chlorella vulgaris by ascorbic acid, calcium, glucose and reduced glulathione. Environ. Poll., 101: 169.

Faulkner, D. J. (1986). Marine natural products. Nature Prod. Rep., 3, 31.

Foyer, C. H. and Ferrario, S. (1994). Modulation of carbon and nitrogen metabolism in transgenic plants with a view to improved biomass production. Biochem. Soc. Trans., 22 (4): 909.

Furuki, M. and Tachibana, S. (1986). A spectrophotometrical study on the effect of vitamin $\mathrm{B}_{2}$ - acid on the growth of Chattonella antique. $J$. fermentation. Technology, 64 (2): 169.

Gowrinathan, K. P. and Rao, V. N. R. (1992). Reversal of heavy metal toxicity by ascorbic acid in microalgae. J. Swamy Botony, 9: 27.

He, Y. and Hader, D. (2002). UV- B- induced formation of reactive oxygen species and oxidative damage of the Cyanobacterium Anabaena sp: protective effects of ascorbic acid and $\mathrm{N}$ - acetyl - cysteine. $J$. photochemistry photobiol., 66: 115.

Hirano, A.; Ueda, R.; Hirayama, S. and Ogushi, Y. (1997). $\mathrm{CO}_{2}$ fixation and ethanol production with microalgal photosynthesis and intracellular anaerobic fermentation. Energy, 22: 137.

Hirata, S.; Hayashitani, M.; Taya, M. and Tone, S. (1996). Carbon dioxide fixation in batch culture of Chlorella $s p$. using a photobioreactor with a sunlight-collection device. J. Ferment. Bioeng., 81: 470.

Korner, S. and Vermaat, J. E. (1998). The relative importance of Lemna gibba L., bacteria and algae for the nitrogen and phosphorus removal in duckweed- covered domestic wastewater. Water Res., 32: 3651.

Lau, P. S.; Tam, N. F. Y. and Wong, Y. S. (1994). Influence of organic- N sources on an algal wastewater treatment system. Resour. Conservation. Recycling, 11: 197. 
Lee, K. Y. and Lee, C. G. (2001). Effect of light/ dark cycles on wastewater treatments by microalgae. Biotechnol. Bioprocess Eng., 6: 194.

Lee, K. Y. and Lee, C. G. (2002). Nitrogen removal from wastewaters by microalgae without consuming organic carbon sources. J. Microbiol. Biotechnol., 12 (6): 979.

Lemmer, H.; Lind, G.; Metzner, G.; Nitschke, L. and Schade, M. (1998). Vitamin addition in biological wastewater treatment. Water Sci. Technol., 37: 395.

Liebler, D. C.; Kling, D. S. and Reed, D. J. (1986). Antioxdant protection of phospholipid bilayers by alpha- to copherol. Control of alpha- to copherol status and lipid peroxidation by ascorbic acid and glutathione. J. Biol. Chem., 261 (26): 121.

Lind, G.; Schade, M.; Metzner, G. and Lemmer, H. (1994). Use of vitamins in biological wastewater treatment. $G W F$-Wasser / Abwasser, 135: 595.

Markus, D. K.; Mckinnon, J. P. and Buceaafuri, A. F. (1982). Automatic analysis of nitrite, nitrate and ammonium- nitrogen in soils. New Jersey Agric. Exp. Stn., Publication no. D 15117- 84 supported by State Funds, presented in part before Division 4 Soil Science Soc. of America, Anaheim, CA, Dec. 2.

Miyamoto, E.; Watanabe, F.; Takenaka, H. and Nakano, Y. (2002). Uptake and physiological function of vitamin $\mathrm{B}_{12}$ in a photosynthetic unicellular coccolithophorid alga, Pleurochrysis carterae. Biosci. Biotechnol. Biochem., 66 (1): 195.

Murakami, M. and Lkenouchi, M. (1997). The biological $\mathrm{CO}_{2}$ fixation and utilization project by RITE (2). Energy. Convers. Mgmt., 38: S493.

Nagase, H.; Eguchi, K.; Yoshihare, K.; Hirata, K. and Miyamoto, K. (1998). Improvement of microalgal NOx removal in bubble column and airlift reactors. J. Ferment. Bioeng., 86: 421.

Padh, H. (1990). Cellular functions of ascorbic acid. Biochem. Cell. Biol., 68 (10):1166.

Radmer, R. J. (1996). Algal diversity and commercial algal products. Bioscience, 46: 263.

Rai, L. C. and Raizada, M. (1988). Impact of chromium and lead on Nostoc muscorum: regulation of toxicity by ascorbic acid, glutathione and sulfurcontaining amino acids. Ecotoxicol. Environ. Saf., 15 (2): 195.

Rowan, A. K.; Moser, G.; Gray, N.; Snape, J. R.; Fearnside, D.; Curtis, T. P.; Barer, M. R. and Head, I. M. (2003). A comparative study of ammonia oxidizing bacteria in lab- scale industrial wastewater treatment reactors. Water Sci. Technol., 48 (3): 17.

Snedecor, G. W. and Cochran, W. G. (1967). Statistical methods. $6^{\text {th }}$ Ed. Iowa State Univ. Press. Ames. Iowa, USA, P. 275. 
Sudhakar, G.; Jyothi, B. and Venkateswarlu, V. (1991). Metal pollution and its impact on algae in flowering waters in India. Archives. Environ. Contamination and Toxicol., 21: 556.

Syrett, P. J. (1981). Nitrogen metabolism of microalgae. In : Physiological Bases of Phytoplankton Ecology, Platt, T. (Ed.) Can. Bull. Fish. Aqua. Sci., 210: 182.

Vonshak, A. (1986). Laboratory techniques for the cultivation of microalgae. Richmond, A, CRC handbook of microalgae mass culture. pp.117.

Vymazal, J. (1995). Algae and element cycling in wetland. By CRC Press, Inc. Lewis Publishers, pp. 689.

Watanabe, F.; Nakano, Y.; Tamura, Y. and Yamanaka, H. (1991). Vitamin $\mathrm{B}_{12}$ metabolism in a photosynthesizing green alga, Chlamydomonas reinhardtii. Biochem. Biophysica. Acta, 1075 (1): 36.

Zhang, Y.; Bicho, P. A.; Breuil, C.; Saddler J. N. and Liss, S. N. (1997). Resin acid degradation by bacterial strains grown on CTMP effluent. Water Sci. Technol., 35 (2-3): 33.

\footnotetext{
دور الفيتامينات فى تحسين المعالجة البيولوجية لمياه المجارى بواسطة الطحالب.

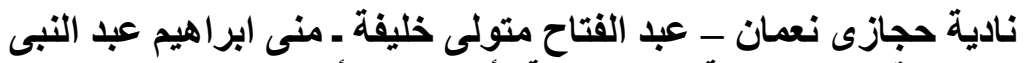

